\title{
Fauzi al-Kawukdżi i Abd al-Kadir al-Husajni w walce o niepodległość Palestyny
}

Streszczenie. Artykuł omawia działania podejmowane przez Fauziego al-Kawukdżiego i Abd al-Kadira al-Husajniego w czasie tzw. wojny domowej w brytyjskim Mandacie Palestyny. Pierwszy stał na czele Arabskiej Armii Wyzwolenia, stworzonej przez Ligę Państw Arabskich. Jego siły miały charakter ochotniczy, były nieliczne i słabo uzbrojone. Drugi powołał Armię Świętej Wojny, która składała się z ochotników palestyńskich, stanowiła siły podporządkowane rodzinie Husajnich. Obaj dowódcy mieli za zadanie nie dopuścić do wejścia w życie rezolucji Organizacji Narodów Zjednoczonych dotyczącej podziału Palestyny na dwa państwa oraz chronić arabską ludność cywilną. Prowadzili działania bez współpracy ze sobą i nie udało im się powstrzymać działań osadników i sił żydowskich.

Słowa kluczowe: Fauzi al-Kawukdżi, Abd al-Kadir al-Husajni, wojna domowa, mandat Palestyny, 1948.

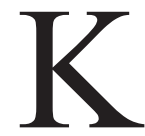

westia niepodległości Palestyny pozostaje w XXI w. sprawą wciąż aktualną i przykuwającą co jakiś czas uwagę opinii publicznej w związku tem rozważań podjętych $\mathrm{w}$ artykule jest pierwszy etap otwartego konfliktu między Arabami zamieszkującymi brytyjski Mandat Palestyny a osadnikami żydowskimi, zwany wojną domową w Mandacie Palestyny (30 listopada - 15 maja 1948 r.). Konflikt ten będzie jednak tłem dla działalności dwóch najsłynniejszych dowódców z tego okresu, tj. Fauziego al-Kawukdżiego oraz Abd al-Kadira al-Husajniego. To oni wzięli na siebie ciężar walki o niepodległość przyszłego państwa arabskiego w Palestynie i borykali się z licznymi przeciwnościami, stojąc na czele nieregularnych sił. Stali po dwóch stronach, a walczyli w imię jednej sprawy: powstania niezależnego państwa arabskiego, przeciwko Żydom przybyłym do Palestyny.

* Wydział Filozoficzno-Historyczny, Instytut Historii, Katedra Historii Polski i Świata po 1945 roku, e-mail: magdalena.pol@uni.lodz.pl 
Na Bliskim Wschodzie lat dwudziestych i trzydziestych XX w. Fauzi al-Kawukdżi był postacią cieszącą się dużą popularnością. Ten urodzony w $1890 \mathrm{r}$. w Trypolisie przyszły wojskowy, licznymi działaniami w kolejnych latach zaskarbił sobie przychylność arabskiej społeczności. W 1912 r. w Stambule ukończył akademię wojskową, co było rzadkością w czasach Imperium Osmańskiego. Al-Kawukdżi kontynuował w tym zakresie tradycję rodzinną - jego ojciec również służył w armii osmańskiej. Brał aktywny udział w pierwszej wojnie światowej w randze kapitana armii osmańskiej. Następnie należał do grona sojuszników Fajsala I i projektu Wielkiej Syrii ${ }^{1}$. Po przejęciu przez Francuzów kontroli nad Syrią znalazł się, choć trudno wyjaśnić w jaki sposób, we Francuskiej Armii Lewantu². Służył w niej jako oficer kawalerii aż do 1925 r., kiedy przyłączył się do powstania Druzów przeciwko Francuzom i walczył w mieście Hama ${ }^{3}$. W konsekwencji francuski wymiar sprawiedliwości skazał go na śmierć, więc zbiegł do Hidżazu (dzisiejsza Arabia Saudyjska). Od tego czasu Fauzi al-Kawukdżi zaangażowany był $\mathrm{w}$ większość wystąpień przeciwko władzom mandatowym, zarówno brytyjskim, jak i francuskim na Bliskim Wschodzie. Jego doświadczenia $\mathrm{z}$ armii osmańskiej i francuskiej wykorzystywane były przez nowo powstałe państwa na Bliskim Wschodzie. W Hidżazie szkolił podobnych do siebie uciekinierów z Syrii, ale naraził się królowi Azizowi ibn Saudowi i musiał opuścić ten kraj. W 1932 r. został zaproszony przez króla Fajsala I do Iraku, gdzie rozpoczął pracę jako wykładowca w akademii wojskowej w Bagdadzie. W czasie powstania antybrytyjskiego w 1936 r. al-Kawukdżi stawił się w Palestynie z 200 ochotnikami na wezwanie pełniącego funkcję wielkiego muftiego Jerozolimy Haj Amina al-Husajniego ${ }^{4}$. Nie były to jednak siły podporządkowane muftiemu, tylko Irackiemu Towarzystwu Obrony Palestyny. Al-Kawukdżi dowodził wojskami w rejonie Nablus-Tulkaram-Jenin, a siłami podległymi al-Husajniemu w okolicach Jerozolimy kierował Abd al-Kadir al-Husajni. To spotkanie z Abd al-Kadirem na polu walki w Palestynie, jak się okazało, nie było ostatnie. Pod naciskiem

${ }^{1}$ Królestwo Wielkiej Syrii powołane zostało w 1920 r. z Fajsalem jako królem. Działanie to miało zapobiec oddaniu obszaru dzisiejszej Syrii i Libanu pod mandatową kontrolę francuską. Niestety Francja przejęła kontrolę nad tym rejonem zgodnie z postanowieniami konferencji w San Remo. Vide: D. Pipe s, Greater Syria. The History of an Ambition, New York 1990; J. M c Hu g o, Syria from the Great War to Civil War, London 2014.

${ }^{2}$ Sam al-Kawukdżi twierdził, że był to rodzaj infiltracji francuskich sił. Laila Parsons w biografii al-Kawukdżiego wskazuje, że mogło to wynikać z konieczności życiowych: w owym czasie ożenił się i urodziły mu się dzieci. L. P ars on s, The Commander, Fawzi al-Qawuqji and the Fight for Arab Independence 1914-1948, New York 2017, s. 72-74.

${ }^{3}$ W 1925 r. w rejonie Dżabal ad-Duruzu wybuchło powstanie na czele z Sultanem Atraszem, będące wynikiem zmian, jakie zaproponował mandatariusz, głównie w obszarze własności ziemi oraz systemu politycznego. Więcej vide: J. Z d a n ow s ki, Historia Bliskiego Wschodu w XX wieku, Wrocław 2010, s. 92 i n.

${ }^{4}$ T. S w e d e n burg, Memories of Revolt. The 1936-1939 Rebellion and the Palestinian National Past, Fayetteville 2003, s. 83. 
Brytyjczyków, po powrocie do Iraku został odsunięty na boczny tor i wysłany do Kirkuku5. W 1941 r. wspierał zbrojny zryw Raszida Kailaniego przeciwko Brytyjczykom, co przyniosło mu dodatkową sławę. Po upadku powstania zaczął się kolejny etap jego życia. Spędził go w III Rzeszy, gdzie zabiegał o wydanie przez tamtejsze władze deklaracji, która potwierdzałaby arabskie aspiracje narodowe, oraz o odpowiednią działalność propagandową w krajach arabskich ${ }^{6}$. W Niemczech przebywał do końca wojny.

Tymczasem po zakończeniu drugiej wojny światowej Wielka Brytania, borykająca się z licznymi trudnościami, zdecydowała się na opuszczenie obszaru mandatowego Palestyny. Decyzja została przedstawiona na forum Organizacji Narodów Zjednoczonych (ONZ), która wzięła na siebie ciężar ostatecznego rozstrzygnięcia sprawy palestyńskiej. W tym celu powołano Specjalny Komitet do Spraw Palestyny (UNSCOP), który miał wypracować rozwiązanie ${ }^{7}$. Decyzja Brytyjczyków zbiegła się w czasie z powrotem al-Kawukdżiego na Bliski Wschód (początek 1947). Wtedy mówił on o sobie, że od urodzenia jest wojskowym i że nie zna się na polityce, ani że nie chce się na niej znać ${ }^{8}$. Ale to właśnie polityka miała zadecydować o jego dalszych losach na Bliskim Wschodzie.

W oczekiwaniu na decyzje ONZ państwa arabskie oraz przedstawiciele Arabów palestyńskich przygotowywali się do spodziewanej konfrontacji z Żydami. Pytanie pozostawało otwarte - jaką ona będzie mieć skalę i kto będzie w nią zaangażowany. Po powrocie na Bliski Wschód al-Kawukdżi znalazł się w centrum tych wydarzeń, debat dotyczących przyszłości i oczekiwań związanych z wycofaniem Brytyjczyków z Palestyny. Postanowił zaangażować się w sprawę palestyńską, zresztą nie po raz pierwszy. W trakcie 10-dniowego pobytu w Kairze (luty 1947) dwukrotnie spotkał się z Haj Aminem al-Husajnim, który zabiegał

${ }^{5}$ Szerzej o działaniach al-Kawukdżiego w czasie powstania 1936-1939 vide: M. Hughes, Britain's Pacification of Palestine. The British Army, the Colonial State, and the Arab Revolt, 1936-1939, Cambridge 2019, s. 121-128.

${ }^{6}$ Na temat kontaktów Fauziego al-Kawukdżiego z ambasadorem Fritzem Grobbą i doświadczenia z III Rzeszy vide: Ł. Hirs zowi c z, III Rzesza i Arabski Wschód, Warszawa 1963, s. 296; G. Hopp, Ruhmloses Zwischenspiel. Fawzi al-Qawuqji in Deutschland 1941-1947, [w:] Al-Rafidayn. Jarhbuch zu Geschichte und Kultur des modernen Iraq, hrsg. P. Heine, Wurzburg 1995, s. 19-46; B. Ru bin, W.G. S chw an itz, Hitlerowcy, islamiści i narodziny nowożytnego Bliskiego Wschodu, Kraków 2014, s. 123, 244-245.

${ }^{7}$ O sprawie palestyńskiej w ONZ vide: Documents of Palestine, ed. M.A. Hadi, vol. I, Jerusalem 2007, s. 467-495; United Nations Official Record of the Second Special Session of the General Assembly, Suplement No. 2, New York 1948; A. P at ek, Wieka Brytania wobec Izraela w okresie pierwszej wojny arabsko-izraelskiej maj 1948 - styczeń 1949, Kraków 2002; M. P o g oń s k a-P o 1, Działalność Komisji Narodów Zjednoczonych do Spraw Palestyny 1947-1948, [w:] W kręgu zagadnień świata arabskiego, red. A. Abbas, A. Maśko, Poznań 2015, s. 335-348; e a de m, Działalność Organizacji Narodów Zjednoczonych w czasie pierwszej wojny arabsko-izraelskiej 1948-1949, [w:] Bezpieczeństwo narodowe i międzynarodowe w regionie Bliskiego Wschodu i Pótnocnej Afryki (MENA) u progu XXI wieku, red. R. Bania, K. Zdulski, Łódź 2012, s. 297-309.

${ }^{8}$ L. Parson, op. cit., s. 202. 
tam o pomoc Ligii Państw Arabskich ${ }^{9}$ i Egiptu dla Arabów palestyńskich. Za każdym razem do spotkania dochodziło z inicjatywy al-Kawukdżiego, ale mimo deklarowanej przez niego pomocy lider palestyńskich Arabów odrzucał jego propozycje. W jednym z wywiadów udzielonych w tym okresie (dziennik Al-Ahram) Fawzi powiedział, że jest gotowy do podjęcia się takich obowiązków, jakie będą mu przydzielone ${ }^{10}$.

Przygotowujący ostateczny raport Komitet Ad Hoc ONZ 3 września 1947 r. zapowiedział, że w dokumencie znajdzie się zapis mówiący o podziale Palestyny na dwa organizmy państwowe (żydowski i arabski). Ta decyzja zastała al-Kawukdżiego w Damaszku, gdzie mieszkał u Ahmada Szarabatiego, syryjskiego ministra obrony. Odbył też w tym czasie szereg rozmów z Szukrim al-Kuwwatlim, prezydentem Syrii, w trakcie których zaproponował swoje usługi w sprawie palestyńskiej ${ }^{11}$.

W odpowiedzi na wspomniane oświadczenie ONZ przedstawiciele państw członkowskich Ligi Państw Arabskich, zebrani w Aley w Libanie (7-9 października 1947), zdecydowali się na powołanie stałego komitetu technicznego. W trakcie spotkania ścierały się ze sobą dwa obozy: egipski - preferujący wysyłanie do Palestyny ochotników - i iracko-syryjski - opowiadający się za skierowaniem sił regularnych ${ }^{12}$. Komitet otrzymał zadanie przygotowania raportu dotyczącego sytuacji militarnej w Palestynie.

Decyzja Zgromadzenia Ogólnego ONZ z 29 listopada 1947 r. o podziale Mandatu Palestyny ${ }^{13}$ na dwa państwa skłoniła Ligę do przekształcenia komitetu technicznego w militarny. Na czele tego gremium stał były iracki szef sztabu, gen. Ismail Safwat. Zdecydował on, że opracowany raport zostanie przedstawiony sekretarzowi Ligii Państw Arabskich Abdul Ramanowi Azzamowi. $\mathrm{Z}$ przygotowanego dokumentu jasno wynikało, że Palestyńczycy nie będą w stanie sami obronić się przed Żydami. Safwat zalecał udział w walce regularnych wojsk państw arabskich, które mogłyby być wsparte przez Palestyńczyków oraz ochotników z krajów arabskich. Proponował natychmiastową rekrutację i szkolenie sił nieregularnych ${ }^{14}$. Na spotkanie w Aley został także zaproszony al-Kawukdżi. Wprawdzie nie pełnił tam żadnej oficjalnej funkcji, jednak uczestniczył

${ }^{9}$ Liga Państw Arabskich powstała 22 III 1945 r. w Kairze. W omawianym okresie zrzeszała następujące państwa: Arabię Saudyjską, Egipt, Irak, Jemen, Transjordanię, Liban i Syrię.

${ }_{10}$ L. Pars o n, op. cit., s. 206-207.

${ }^{11}$ Ibidem, s. 211-212.

${ }_{12}$ R. Yitzhak, The Question of Arab Solidarity in the 1948 War: Political Interest versus Military Considerations, „Mediterranean Quarterly” 2008, vol. XIX, No. 2, s. 20-21.

13 Rezolucja Zgromadzenia Ogólnego ONZ w sprawie podziału Palestyny z dnia 29 XI 1947 r., [w:] Bliski Wschód: dokumentacja konfliktu. Seria monograficzna, z. 3 (184), Warszawa 1983, s. 5-10; H. J a m s h e er, Konflikt Bliskowschodni. Zarys i dokumentacja, Płock 2004, s. 42-47.

${ }^{14}$ W. Khalidi, Selected Documents on the 1948 Palestine War, „Journal of Palestine Studies” 1998, vol. XXVII, No. 3, s. 62. 
w rozmowach. W trakcie obrad zastanawiano się, komu powierzyć dowództwo nad tymi oddziałami. Wśród rozpatrywanych kandydatur znalazł się al-Kawukdżi. Nie był to zapewne przypadek, jako jeden z niewielu bowiem miał doświadczenie w walce partyzanckiej, ponadto jego osoba nie wywoływała sporów między członkami Ligi ${ }^{15}$. Kandydatura ta budziła natomiast niepokój i obawy muftiego, który rozpoczął akcję mającą na celu zdyskredytowanie Fauziego ${ }^{16}$.

Szczegóły dotyczące użycia arabskich wojsk omawiano na spotkaniu w Kairze (8-17 grudnia). W tym czasie jednak żadne $\mathrm{z}$ państw arabskich nie dysponowało siłami, które można by było szybko użyć, były to bowiem armie stosunkowo młode. Przywódcy arabscy zignorowali zalecenia wynikające z raportu i zdecydowali o wysłaniu do Palestyny jedynie sił złożonych z ochotników ${ }^{17}$.

Formując Arabską Armię Wyzwolenia, opierano się głównie na Syrii, która była zainteresowana prowadzeniem wojny prewencyjnej. Decyzja ONZ wpłynęła na kształt sił formowanych pod auspicjami Ligi Państw Arabskich. Arabowie wylegli na ulice i protestowali, tak jak ich rządy, przeciwko rozwiązaniu zaproponowanemu przez ONZ. Nastąpiło spontaniczne wsparcie dla koncepcji walki oraz napływ licznych ochotników w szeregi formowanych oddziałów. Pojawili się darczyńcy gotowi przekazywać środki na ochotniczą armię arabską, która walczyłaby z Żydami. Na początku grudnia 1947 r. głównym inspektorem sił ochotniczych został Taha al-Hashimi, a 6 grudnia al-Kawukdżiego powołano na dowódcę polowego, po czym 5 stycznia 1948 r. oficjalnie utworzono Arabską Armię Wyzwolenia. Al-Kawukdżi decydując się na zostanie dowódcą arabskich sił ochotniczych, podjął się wykonania właściwie niemożliwego zadania. Musiał przygotować siły w kilka tygodni. Został dowódcą, bo właściwie oprócz muftiego nikt nie chciał objąć tej funkcji ${ }^{18}$. Al-Kawukdżi był zwolennikiem wojny ludowej, uważał ją za skuteczną już od 1936 r. i to mogło mieć wpływ na podejmowane przez niego decyzje ${ }^{19}$. Ponadto twierdził, że udział w tej wojnie armii

15 L. Parsons, op. cit., s. 220-221.

16 Konflikt między muftim a al-Kawukdżim trwał od połowy lat trzydziestych, nasilił się w czasie pobytu w III Rzeszy, kiedy to al-Husajni oskarżał al-Kawukdżiego o bycie brytyjskim szpiegiem. W 1947 r. mufti przekonywał prezydenta Syrii, że Fawzi sprzyja królowi Transjordanii Abdullahowi. Vide: L. Pars on s, op. cit., s. 213-214; G.H. Talh a mi, Syria and the Palestinians. The Clash of Nationalisms, Gainesville 2001, s. 29.

17 Wynikało to być może z potrzeby osłabienia klanu al-Husajnich. Działania przez nich podejmowane zaktywizowały Ligę do stworzenia siły, która byłaby przeciwwagą dla Armii Świętej Wojny, uznawanej za ich prywatną armię. Wpływ na decyzję o wysłaniu tylko sił ochotniczych brał się również z potrzeby ograniczenia wpływów króla Transjordanii Abdullaha, który zmierzał do przyłączenia Palestyny do jego państwa. Monarcha Transjordanii uzyskał nawet w tym zakresie wsparcie rządu brytyjskiego - miał ograniczyć się do obszarów przewidzianych dla Arabów w dokumentach ONZ. Vide: D. Ta 1, War in Palestine 1948. Strategy and Diplomacy, London-New York 2004, s. 15-17; B. Wrób lew s k i, Legion Arabski (1920-1957), Toruń 2009, s. 84-85.

18 L. Parsons, op. cit., s. 221.

19 G.H. Talh m i, Syria and the Palestinians. The Clash of Nationalisms, Gainesville 2001, s. 18. 
regularnych powinien być ostatecznością, mógł nastąpić dopiero wówczas, gdy siły nieregularne przygotują odpowiednie możliwości ich operowania ${ }^{20}$.

Z założenia siły składać się miały z ochotników pochodzących z państw arabskich. Bazy armii znajdowały się w Syrii, w okolicy miejscowości Katana. Lokalizacja wybrana została ze względu na położenie niedaleko Damaszku oraz warunki geograficzne - wzgórza, które umożliwiły szkolenie artylerzystów. Armię tworzyło: 1000 Palestyńczyków, 2000 Egipcjan, 3000 Syryjczyków i kilkuset ochotników z innych państw arabskich. Syryjscy oficerowie i mężczyźni mogli zgłaszać się jako instruktorzy, a nawet ochotnicy do jednostek bojowych. W grudniu 1947 r. kilku syryjskich oficerów zrezygnowało ze swoich stanowisk w armii, aby dołączyć do wojsk ochotniczych ${ }^{21}$. Inne źródła podają, że al-Kawukdżiemu towarzyszyły siły składające się z około 4000 żołnierzy ${ }^{22}$. Według opinii Amerykanów z końca stycznia 1948 r. w Syrii zrekrutowano około 16000 ochotników, lecz jak wskazuje ten sam raport, tylko niewielka część była przeszkolona i posiadała mundury. Duża liczba ochotników stanowiła nie lada wyzwanie dla władz syryjskich, które zobowiązały się ich uzbroić. W dokumencie podkreślono, że nie spodziewano się tak dużego odzewu ${ }^{23}$. Jednak w niektórych regionach trzeba było obecności al-Kawukdżiego, aby zachęcić młodych do udziału w armii. Pod koniec grudnia 1947 r. odbył on podróż na północ, aby przekonać Druzów do udziału w wojnie ${ }^{24}$.

Siłom dowodzonym przez al-Kawukdżiego postawiono zadanie nie tylko walki z Żydami, zapobiegnięcia podziałowi i powstania państwa żydowskiego, lecz także ochrony ludności arabskiej w Mandacie Palestyny. Miał to zrealizować poprzez opanowanie dróg pomiędzy osadami żydowskimi oraz atakami na konwoje. Zdawano sobie sprawę z przewagi przeciwnika, dlatego ważnym elementem stało się zbieranie informacji i rozpoznanie terenu, tak aby maksymalnie wykorzystać możliwości sił arabskich ochotników. Planując bitwy o drogi, osady i potyczki z żydowską Haganą, al-Kawukdżi musiał uwzględniać słabe wyposażenie i uzbrojenie swoich sił oraz przewagę przeciwnika w wyszkoleniu. Bolączką całej sytuacji było to, że nie udało się opracować ani wprowadzić w życie

20 Ibidem, s. 30 .

21 D. As her, The Arab Armies Invasion of Israel, May 1948 Interests and Implementation, http://institutobrasilisrael.org/cms/assets/uploads/_BIBLIOTECA/_PDF/o-conflito-a\%CC\%81 rabe-israelense/e3a7b434ee05a3364268abcb818e9ff4.pdf (dostęp: 11 IX 2018). Brytyjczycy w tym okresie odnotowali, że siły ochotnicze były trenowane także przez Europejczyków, prawdopodobnie niemieckiego pochodzenia.

${ }^{22}$ F. a l-Q aw uqj i, Memoirs, 1948, Part I, „Journal of Palestine Studies” 1972, vol. I, No. 4, s. 31; L. P ars on s, op. cit., s. 226.

${ }^{23}$ Foreign Relation of United States, 1948, The Near East, South Asia and Africa, vol. V (Foreign Relation of United States, 1948), part 2, Washington 1976, s. 555-556.

24 L. Parsons, op. cit., s. 225. 
planu operacyjnego dla wszystkich sił. W rzeczywistości każdy z dowódców mógł podejmować własne decyzje, zależne od bieżącej sytuacji ${ }^{25}$.

Arabska Armia Wyzwolenia podzielona została na osiem batalionów ${ }^{26}$. Każdy dowodzony był przez innego oficera i w innym czasie, różnymi drogami przedostawały się one do Palestyny. Dla dowódców kluczowe było zapewnienie możliwości przejścia przez Transjordanię, za co odpowiedzialny był sam al-Kawukdżi, z czym miał jednak duże kłopoty. Władze tego państwa protestowały przeciwko przemarszom przez ich terytorium ochotników z Arabskiej Armii Wyzwolenia ze względu na umowę z Brytyjczykami. Al-Kawukdżi musiał się sprawdzić w roli dyplomaty i znaleźć wyjście z sytuacji. Oczywiście powołał się na swoich znajomych oraz autorytet Ligi Państw Arabskich. Przeprawa została ustalona z królem Abdullahem i pierwszy batalion mógł przekroczyć Jordan po moście Damia ${ }^{27}$. Kiedy jednak Brytyjczycy zorientowali się w sytuacji, zablokowali przejście, uniemożliwiając al-Kawukdżiemu wysyłanie tą drogą zaopatrzenia. Później więc do przerzutu zaopatrzenia dla swych sił wykorzystywał szlak prowadzący przez most Allenby'ego ${ }^{28}$. Niespodziewanie dla niego Brytyjczycy zobligowali go w tym czasie, jak twierdził, do bycia odpowiedzialnym za bezpieczeństwo całego obszaru mandatu, ale dowództwo powierzyło mu jedynie obszar NablusJenin-Tulkram i obszar Galilei ${ }^{29}$.

Al-Kawukdżi był - można powiedzieć - w trudnej sytuacji: musiał dostarczyć sprzęt i umundurowanie, pieniądze na żołd, zapewnić logistykę i zaopatrzenie sił z terytorium Libanu i Syrii, tak aby nie narażać się na nieprzychylność arabskiej ludności wiejskiej. Właściwie po pierwszych kłopotach z przekroczeniem terytorium Transjordanii nie było problemu z operowaniem na obszarze Galilei, wojska brytyjskie się temu nie sprzeciwiały. Na początku stycznia, kiedy siły al-Kawukdżiego zaczęły walczyć w Palestynie (2 batalion Yarmuk) w okolicach Yehiam, realizowano plan zdobywania żydowskich osiedli. Ta pierwsza potyczka z 20-21 stycznia 1948 r. zakończyła się porażką 2 batalionu dowodzonego przez Adiba Sziszakliego. Żydom z pomocą przyszli wówczas Brytyjczycy. Al-Kauwkdżi jednak nie zamierzał rezygnować ${ }^{30}$. Kolejne bataliony pojawiały

${ }^{25}$ A. Ezov, Arab army vs. a Jewish kibbutz: the battle of MishmarHa' emek, April 1948, „Israel Affairs" 2016, vol. XXII, No. 1, s. 98-99.

${ }^{26}$ Były to: 1 batalion Yarmouk (dowódca: Muhammad Safa), 2 batalion Yarmouk (dowódca: Adib Sziszakli - późniejszy prezydent Syrii), 3 batalion Yarmouk (dowódca: Abd al Hamid al-Rawi), batalion Hittin (dowódca: Madlul Abbas); batalion Husajn (dowódca: Adel Najm al-Din), batalion Kadisija (dowódca: Mahi Saleh), batalion Druzów (dowódca: Szahib Wahab) oraz ochotnicy z Libanu i Czerkiesi pod dowództwem Abu Bakra.

${ }^{27}$ F. al-Q aw u qj i, op. cit., s. 28.

${ }^{28}$ L. Parsons, op. cit., s. 228.

${ }^{29}$ F. a l-Q aw uqj i, op. cit., s. 31-34.

${ }^{30}$ H. Levenberg, Military Preparations of the Arab Community in Palestine 1945-1948, London 1993, s. 193-194. 
się w Palestynie pod koniec stycznia, w marcu oraz kwietniu 1948 r. Dowódca liczył, że wraz z nadejściem oddziałów Arabskiej Armii Wyzwolenia na terytorium objętym mandatem lokalni ochotnicy zasilą jej szeregi w większej liczbie. Tak się jednak nie stało, a odpowiedzialnym za taki stan rzeczy był Haj Amin al-Husajni. Podjął on akcję informacyjną dyskredytującą siły al-Kawukdżiego oraz jego umiejętności jako dowódcy. Jednak mufti, nie mając wyjścia, będąc uzależnionym od sił i środków pochodzących od członków Ligi Państw Arabskich, zaakceptował obecność al-Kawukdżiego. Ten rozłam między nimi doprowadził do tego, że liczba ochotników z Palestyny, napływająca zarówno do Arabskiej Armii Wyzwolenia, jak do Armii Świętej Wojny, była niewielka.

Pierwsze potyczki w Palestynie nie przyniosły armii al-Kawukdżiego sukcesów. Zdecydowanie pospieszył się on z wysyłaniem sił do mandatu, co mogło być skutkiem napięć między nim a al-Husajnim, co negatywnie przełożyło się na ich zdolności bojowe. Przykładem może być starcie, jakie 16 lutego 1948 r. stoczył 1 batalion Yarmouk, dowodzony przez Muhammada Safę pod Tirat Cewi (al-Zarra'a). Jego oddział poniósł ciężkie straty, a kibuc nie został zdobyty. Celem tej akcji było nie tylko pokonanie Żydów, lecz także podniesienie upadającego podczas nieobecności w Palestynie al-Kawukdżiego morale armii. On sam jako główne przyczyny odwrotu sił ochotniczych podał warunki atmosferyczne oraz udział brytyjskich sił po stronie żydowskiej ${ }^{31}$. Pomimo porażki morale zostało podniesione, dodatkowo udało się przejąc kontrolę nad drogami do Jerozolimy. Izolacja Starego Miasta oraz odcięcie osiedli położonych wokół niego spowodowały, że siły arabskie miały przewagę psychologiczną, co pomogło im odnieść kolejne sukcesy w marcu $1948 \mathrm{r}$.

Przez dłuższy czas al-Kawukdżi kontaktował się ze swoimi batalionami za pomocą telegramów, nie było go bowiem w Palestynie, dokąd przesyłano zaszyfrowane informacje ${ }^{32}$. Przybył do mandatu dopiero 6 marca 1948 r. Jego kwatera znajdowała się w miejscowości Jaba ${ }^{33}$. Tymczasem Brytyjczycy widząc ruchy wojsk, oceniali, że al-Kawukdżi pojawi się w Palestynie wtedy, kiedy wszystko będzie przygotowane i będzie mógł się wykazać swoim doświadczeniem ${ }^{34}$. Na drodze do wzmocnienia jego pozycji stanęły mu ponownie zabiegi podejmowane przez muftiego w Damaszku, które doprowadziły w lutym 1948 r. do podziału Palestyny na cztery strefy, każda pod innym dowództwem. Al-Kawukdżi został przeniesiony na obszar walki o drugorzędnym znaczeniu, w okolicach Jerozolimy miała operować Armia Świętej Wojny.

W świetle raportu przygotowanego pod koniec marca 1948 r. Arabska Armia Wyzwolenia była w trudnej sytuacji. Jeśli chodzi o wyposażenie w broń,

${ }^{31}$ F. al-Q awu quj i, op. cit., s. 36-37.

${ }^{32}$ Szyfr został przedstawiony przez E. Taubera. Vide: E. Tauber, Palestine 1948: the cryptography of the Arab volunteers, „Journal of the Intelligence History” 2013, vol. XII, No. 1, s. 38.

${ }^{33}$ F. a l-Q a w u qj i, op. cit., s. 29.

34 The British Record of Partition, „The Nation” 1948, vol. CLXVI, part 2, s. 9. 
dysponowała niewielką jej liczbą, głównie pochodzącą z okresu drugiej wojny światowej, jeszcze gorzej było $\mathrm{z}$ amunicją. Siły dowodzone przez al-Kawukdżiego miały wówczas na stanie nie więcej niż 14 moździerzy, a te operujące w miastach nie dysponowały ani jednym. Jedyne działa („stare armaty” - jak określał je w raporcie Ismail Sawfat) trafiły na północ mandatu. W przeciwieństwie do strony żydowskiej nie posiadano czołgów, pojazdów opancerzonych ani wsparcia lotnictwa ${ }^{35}$. Mimo to dowódca liczył, że zdoła odnieść spektakularne zwycięstwo. Al-Kawukdżi zdawał sobie sprawę z niebezpieczeństwa, jakim było wycofanie Brytyjczyków. Oznaczało to ni mniej, ni więcej, tylko zagrożenie dla arabskich miast, w ich kierunku bowiem skierować się miały siły żydowskie. Wprawdzie jego zdanie podzielał nadzorujący go komitet w Damaszku, jednak nie przełożyło się to na wzmożenie dostaw uzbrojenia, które umożliwiłyby toczenie skutecznej walki z Żydami w obszarze miejskim ${ }^{36}$. Mimo to zdecydował się na atak na Miszmar ha-Emek. Bitwa (4-14 kwietnia 1948) nie przyniosła Fauziemu upragnionego sukcesu. Ukazała jednak nowe możliwości Arabskiej Armii Wyzwolenia. Al-Kawukdżi zaplanował tę operację szczegółowo, skoncentrował siły oraz zdecydował się na użycie dział dostarczonych przez Syryjczyków ${ }^{37}$. Przejęcie kibicu dawałoby mu szereg możliwości, znajdował się on bowiem na drodze Jenin-Hajfa. Istniała możliwość opanowania Wadi Milik - głównej drogi łączącej północ z południem Palestyny i podzielenia kraju na pół. Dyskusyjne pozostaje, czy chciał opanować Hajfę i czy wystarczyłoby mu na to sił, zważywszy na to, że nie zalecał konfrontacji na dużą skalę z lepiej przygotowaną Haganą. Wierzył, że jego własne umiejętności i doświadczenie wojskowe pozwolą na odniesienie zwycięstwa, a sukces w bitwie zapewnić mu miało bycie głównodowodzącym wszystkich sił w Palestynie. Jednak przebieg bitwy ujawnił wszystkie niedostatki Arabskiej Armii Wyzwolenia: mierność dowódców, niskie morale, słabe wyszkolenie, brak współpracy ${ }^{38}$. Nie udało mu się także uchronić Hajfy, istotnego portu w Palestynie. Wprawdzie nie walczył tam bezpośrednio, ale jego wojsko było zobowiązane do ochrony miasta.

Porażka wojsk arabskich pod Miszmar ha-Emek była ważnym momentem w trakcie wojny domowej - podniosła morale żydowskie po niepowodzeniach, jakich Hagana doznała w marcu 1948 r. Zbliżał się także termin wycofania Brytyjczyków. Te wydarzenia skłoniły al-Kawukdżiego do przerzucenia batalionów

${ }^{35}$ Sytuację Arabskiej Armii Wyzwolenia opisuje w Raporcie dla Ligi Arabskiej gen. Ismail Sawfat, podkreślając, że przy takim stanie posiadania zwycięstwo nad Żydami nie było możliwe. Remedium mogły być jedynie siły regularne. Vide: The Military Situations in Palestine in the eve of Plan Dalet, ,Journal of Palestine Studies” 1990, vol. XXVII, No. 3, s. 62-72.

${ }^{36}$ G.H. Talh a mi, op. cit., s. 31.

${ }^{37}$ Szerzej o bitwie: F. a l-Q a w u qji, op. cit., s. 38-45; A. Ezov, op. cit., s. 96-125.

${ }^{38}$ Przyczyny porażki można także potwierdzić w raportach wysyłanych do Centralnego Dowództwa w Damaszku. W pierwszych miesiącach dotyczyły głównie aprowizacji, rozmieszczenia sił, później widać upadające morale, brak środków finansowych, zapasów, amunicji. F. al-Q a w u qji, Memoirs, 1948, Part II, „Journal of Palestine Studies” 1972, vol. II, No. 1, s. 3-33. 
w rejon najważniejszy w owym momencie, czyli w okolice Jerozolimy, ale niczego istotnego nie osiągnął. Po wkroczeniu do Palestyny regularnych armii arabskich (15 maja) jego pozycja zdecydowanie osłabła. Nie bardzo wiedziano, co zrobić z jego usługami. Ostatecznie siły Arabskiej Armii Wyzwolenia zostały ponownie skierowane do walki na północnym wschodzie Palestyny. Jednak zmalały w wyniku dezercji do około 1000 ludzi i nie odgrywały istotnej roli w walce. Sam al-Kawukdżi zaś pozostawał przez większość czasu poza Palestyną, próbując przekonać Ligę i rządy państw arabskich do dalszego wspierania jego formacji.

Drugi z zasłużonych dowódców arabskich - Abd al-Kadir al-Husajni był postacią zupełnie inną od al-Kawukdżiego. Należał do jednego z dwóch najznamienitszych rodów w Palestynie - historia jego rodziny to historia palestyńskiej walki o niepodległość. Był spokrewniony z byłym wielkim muftim Jerozolimy Haj Aminem al-Husajnim, obaj uczestniczyli w działaniach politycznych i militarnej walce z kolonizatorami, a następnie Żydami.

Al-Husajni urodził się w Stambule w 1908 r. Ukończył studia na Uniwersytecie Amerykańskim w Kairze. Już w czasie studiów zafascynował się hasłami nacjonalistycznymi. W 1933 r. zamieszkał w Jerozolimie i rozpoczął pracę jako urzędnik, jednak dość szybko z niej zrezygnował, by dołączyć do Arabskiej Partii Palestyńskiej ${ }^{39}$. Walczył w arabskim powstaniu przeciwko Brytyjczykom w 1936 r. w okolicach Jerozolimy i tam nabierał doświadczenia wojskowego. Później, podobnie jak al-Kawukdżi, brał udział w walkach w czasie powstania Kailaniego. W czasie bitwy pod Sadr Abu Gharib dostał się do niewoli i trafił do miasta Zakhu. Wskazuje się także, że kiedy w Bagdadzie w 1941 r. zginął członek opozycyjnej wobec Husajnich rodziny Naszaszibich, to właśnie al-Husajni był podejrzewany o udział w tym zabójstwie. Został nawet w związku z tym przesłuchany i uwięziony, na wolność wyszedł dopiero w 1943 r. Po opuszczeniu więzienia udał się do Arabii Saudyjskiej, skąd kilkukrotnie wyjeżdżał do III Rzeszy ${ }^{40}$. W 1946 r. pojawił się w Egipcie, gdzie z namaszczenia muftiego zajął się pozyskiwaniem broni na potrzeby walki z Żydami. Większość pozyskanego przez niego uzbrojenia zdobywano na pustyni, gdzie wciąż znajdowało się wiele sprzętu pozostawionego przez armię niemiecką. Zgromadzoną w ten sposób broń przemycano do Palestyny przez port w libańskim Sydonie ${ }^{41}$. Abd al-Kadir al-Husajni to nie była osoba przypadkowa, jeśli idzie o kierowanie walkami w Mandacie,

${ }^{39}$ Arabska Partia Palestyńska została założona w 1935 r. na zjeździe w Jerozolimie. Na czele partii oficjalnie stanął Dżamal al-Husajni. Stanowiła zaplecze polityczne rodziny Husajnich. Więcej na ten temat vide: M.A. Tess ler, A History of the Israeli-Palestinian Conflict, BloomongtonIndianapolis 1994, s. 229 i n.; I. P a p pe, The Rise and Fall of a Palestinian Dynasty, The Husaynis 1700-1948, Berkeley-Los Angeles 2010, s. 267.

${ }^{40}$ B. Rubin, W.G. Schwanitz, op. cit., s. 244-245.

${ }^{41}$ Abd al-Qadir al-Husseini, https://www.paljourneys.org/en/biography/9831/abd-al-qadir-alhusseini (dostęp: 12 VI 2018). 
Arabowie palestyńscy mówią o nim jako o największym palestyńskim dowódcy polowym. Z pewnością obok Hasana Salamy ${ }^{42}$ jest jednym z nielicznych, którzy zasługują na takie miano.

Tymczasem klan Husajnich - po decyzji ONZ o podziale Mandatu Palestyny - również szykował się do wojny. W Palestynie, w okresie poprzedzającym pierwszą wojnę arabsko-izraelską działały arabskie organizacje o charakterze paramilitarnym. Jedną z nich była al-Najda powstała w $1945 \mathrm{r}$. w Jaffie ${ }^{43}$. W mieniemaniu Arabów miała stać się odpowiednikiem żydowskiej Hagany. Została jednak przejęta przez ród Husajnich z zamiarem stworzenia na jej podstawie przyszłej armii palestyńskiej. Nie wszyscy chcieli się podporządkować przywództwu tego klanu. Wobec braku konsesusu powrócili oni do próby reaktywacji al-Futuwa, którą utworzyli w latach trzydziestych XX w. Świadomość okoliczności, w których toczyła się sprawa przyszłości Palestyny, szczególnie po przejęciu tej kwestii przez ONZ, skłoniła organizacje arabskie do zjednoczenia, przy naciskach ze strony muftiego oraz przewodniczącego Ligi Państw Arabskich. W wyniku konsolidacji utworzono Arabską Organizację Młodzieży, jednak nie dorównywała ona podobnym organizacjom żydowskim - wyszkolenie było słabe, powierzchowne. Trudno wskazać, ile osób zostało nim objętych. O jej działaniach, dowódcach decydować chciał mufti, co rodziło liczne komplikacje i osłabiło zarówno morale już zrekrutowanych, jak i zmniejszyło napływanie nowych członków. W dużym stopniu ambicje al-Husajniego wpłynęły negatywnie na możliwości obrony i prowadzenia skutecznych działań przez Arabów. Starał się on jednak przekonać państwa arabskie do wsparcia sprawy palestyńskiej w postaci dotacji finansowych i dostaw uzbrojenia. Nie chciał wkroczenia arabskich armii narodowych do Palestyny. Na wspomnianym spotkaniu w Aley al-Husajni uzyskał zgodę od przedstawicieli Ligi Państw Arabskich na stworzenie sił wewnątrz Palestyny ${ }^{44}$. Muftiemu nie udało się przeforsować kandydatury Abd al-Kadira al-Husajniego na dowódcę sił ochotniczych tworzonych przez Ligę, ale został on dowódcą sił tworzonych w Palestynie.

W grudniu 1947 r. al-Kadir przybył na obszar mandatu z Egiptu i rozpoczął przygotowania do formowania Armii Świętej Wojny. Mufti liczył, że jego przyjazd do Palestyny pomoże uczynić siły ochotnicze bardziej profesjonalnymi

${ }^{42}$ O działalności Hasana Salamy vide: British Criminal Investigation Department, Israel State Archive, P 3056/38.

${ }^{43}$ Oficjalnie była to organizacja sportowa. Na jej czele stał Muhammad Nimr al-Hawwari. Miała kilka oddziałów, m.in. w Gazie, Ramli, Jerozolimie, Nablusie. Podstawową jednostką była drużyna składająca się z ośmiu osób, trzy drużyny tworzyły kompanię, a batalion dwie i więcej kompanii. Obowiązywały mundury, stopnie odpowiadające wojskowym, każdy z członków musiał wspierać organizację finansowo. Obszerniej na ten temat vide: E. Ta u ber, The Arab Military Force in Palestine Prior to the Invasion of the Arab Armies 1945-1948, „Middle Eastern Studies” 2015, vol. LI, No. 6, s. 951 i n.

${ }^{44}$ Ibidem. 
i zbliżonymi do struktur armii. Wspierać go miał inny z doświadczonych dowódców - Hasan Salama. Zdecydowano (25 grudnia), że swoją nazwą organizacja będzie nawiązywać do tej stworzonej w 1931 r. przez Abd al-Kadira (Armia Świętej Wojny). Siedzibą organizacji miała być Surifa na Górze Hebron. Początkowo formacja nie cieszyła się zaufaniem, należało do niej od 25 do 300 osób. Opierała się na ochotnikach wyszkolonych w obozie w Kantana w Syrii, również tych przynależących wcześniej do al-Futuwy oraz Arabskiej Partii Palestyńskiej. Kiedy Abd al-Kadir przybył do Jerozolimy, zastał tam lokalnych dowódców arabskich milicji, m.in. Jasina al-Bakriego, którzy nie chcieli mu się podporządkować. Mimo to dowódca Armii Świętej Wojny postanowił przejąć kontrolę nad tym obszarem, jednak nie udało mu się tego osiągnąć. Zdecydował się więc przenieść poza Jerozolimę, co wydawało się dawać większe możliwości działania. Na swoją siedzibę wybrał Bir Zayt, wioskę nieopodal Jerozolimy. Tam w sześciu budynkach powstała kwatera główna wojsk al-Husajniego ${ }^{45}$. Siły składały się z trzech grup ochotników: zmobilizowanych, sfinansowanych i uzbrojonych przez Wysoki Komitet Arabski, tworzących mobilne siły uderzeniowe, mogące prowadzić działania przeciwko osadom żydowskim; wojska garnizonowego - walczącego w obronie własnych osad i miast; ochotników, którzy byli w stanie sami zaopatrzyć się w broń i walczyć w obronie własnego dobytku. Al-Husajni miał jednak podstawowy problem: o ile mógł decydować o tym, co dzieje się w Bir Zayt, o tyle miał ograniczone możliwości oddziaływania na cały obszar mandatu. Lokalni dowódcy w dużej mierze podejmowali decyzje samodzielnie, reagując na lokalne zagrożenia. Ponadto borykał się z kłopotami finasowymi i niedostatkiem uzbrojenia. W związku z tymi przeciwnościami zdecydował, że działania będą rozpoczynane przez dobrze wyszkoloną i wyposażoną grupę ludzi, a kontynuowane przez ochotników z poszczególnych obszarów. Tym sposobem mógł dysponować dużymi siłami ${ }^{46}$. Zgodnie z wolą muftiego komitet militarny Ligi Państw Arabskich w Damaszku podzielił obszar Palestyny na cztery części. W każdym z wydzielonych rejonów określono dowódcę: na północy, obszar Galilei - Adib Sziszakli; front centralny, reszta obszaru Mandatu, bez pustyni Negew - F. Kawukdżi; południowy Negew - egipski płk Ahmad Abd al-Aziz ${ }^{47}$. Całością sił wywodzących się z mandatu dowodził Abd al-Kadir al-Husajni, operujący w czwartym rejonie, okolicach Jerozolimy. Trudno precyzyjnie określić liczebność tych sił, w lutym 1948 r. oscylowała od kilkuset po kilka tysięcy osób. Al-Husajni cieszył się dużą estymą. Jednak braki w komunikacji

45 Ibidem.

46 E. Tauber, Palestine $1948 \ldots$, , s. 38.

47 Szerzej o udziale sił ochotniczych i armii egipskiej w konflikcie vide: Mohamed Hassanein Heikal, Reflections on a Nation in Crisis, 1948, „Journal of Palestine Studies” 1988, vol. XVIII, No. 1, s. 112-120; G.A. N a s s e r, Nasser's Memoirs of the First Palestine War, „Journal of Palestine Studies" 1973, vol. II, No. 2, s. 3-32. 
z muftim i podporządkowanie sił komitetowi militarnemu w Damaszku ograniczały skuteczność formacji. Najważniejsze sukcesy wiążą się z aktywnością samego al-Husajniego.

Podstawowym problemem pozostawało uzbrojenie, które pochodziło z zakupów bądź darowizn, głównie z Egiptu. Był to sprzęt różnej jakości i rodzaju, co sprawiało, że jego użytkowanie było często kłopotliwe. W związku z tym konieczne stało się wyznaczenie jednej osoby odpowiedzialnej za dystrybucję i naprawę sprzętu. Al-Husajni zdecydował się powierzyć to zadanie Ibrahimowi Abu Diyi ${ }^{48}$.

Zasadniczym celem al-Husajniego i jego armii było opanowanie jak największego obszaru, tak by móc powstrzymać podział Palestyny, a w przyszłości zbudować niepodległe państwo. Mufti zabiegał o pomoc dla Arabów palestyńskich w Egipcie na początku 1948 r., ale rząd egipski z dużym dystansem odnosił się do sytuacji w Mandacie. Egipcjanie, którzy wsparli walki w Palestynie, byli głównie członkami Bractwa Muzułmańskiego ${ }^{49}$. Siły dowodzone przez al-Kadira w rejonie Jerozolimy podejmowały próby przejęcia kontroli nad drogą łączącą Jaffę z Jerozolimą. Już 14 stycznia 1948 r. rozpoczęto działania w rejonie Gush Etzion, leżącego na południe od Jerozolimy. Słaba koordynacja działań pomiędzy oddziałem al-Husajniego (300 osób) a lokalnymi ochotnikami wezwanymi do walki doprowadziła do porażki. Wpływ na wynik starcia mogło mieć to, że mierzyły się one z oddziałem elitarnego żydowskiego Palmachu ${ }^{50}$. Doświadczenia z pierwszych potyczek wskazały al-Husajniemu, że jego armia powinna być bardziej scentralizowana, a jej możliwości bojowe winno się wykorzystywać maksymalnie. Przełożyło się to również na proces szkolenia. Zdecydował się zaprzestać ataków na osady i położył nacisk na walki w mieście oraz wzdłuż szklaków komunikacyjnych. Dowódca Armii Świętej Wojny zdawał sobie bowiem sprawę z tego, że oddziały Arabskiej Armii Wyzwolenia nie przyjdą mu z pomocą. Walka o drogi okazała się w dłuższej perspektywie rozwiązaniem nieskutecznym, ponieważ do ochrony żydowskich konwojów zobowiązali się Brytyjczycy ${ }^{51}$. Ponadto do zabezpieczania szlaków komunikacyjnych zobowiązane zostały również oddziały Hagany.

Doświadczenia zebrane podczas walk w mieście skłoniły al-Husajniego do używania na większą skalę materiałów wybuchowych, samochodów pułapek. Przykładami realizacji tej taktyki były ataki bombowe na ulicach: Ben Jehuda (22 lutego) oraz Hasolel, a także na budynek Palestine Post (1 lutego) oraz Agencji Żydowskiej w Jerozolimie i konsulatu amerykańskiego (11 marca $)^{52}$.

48 E. Tauber, The Arab Military..., s. 961; i d e m, Palestine 1948..., s. 38.

49 Mohamed Hassanein Heikal..., s. 116.

50 D. Ta 1, War in Palestine 1948. Strategy and Diplomacy, London-New York 2004, s. 53.

51 Ibidem, s. 54.

52 I. Radai, Palestinians in Jerusalem and Jaffa, 1948. A tales of two cities, London-New York 2016, s. 187. 
Działania w rejonie Jerozolimy koncentrowały się na Starym Mieście, okolicach Qatamon, Shaykh Jarrah, Bab al-Wad i Kastel. Al-Husajni przyznawał się do zamachów dokonywanych w Jerozolimie. Po ataku na siedzibę gazety „Palestine Post” wskazał powód tego czynu: „bo zatruwa opinię publiczną w Palestynie"53.

Ostatnim akordem działalności al-Husajniego na rzecz niepodległości Palestyny stała się bitwa pod Kastel. Wsparcia udzielili mu wówczas prawdopodobnie Jugosłowianie, którzy mieli doświadczenie w walce partyzanckiej, oraz Niemcy, którzy w marcu 1948 r. dołączyli do Salamy ${ }^{54}$. Wioska Kastel miała szczególne znacznie strategiczne. Położona $10 \mathrm{~km}$ na zachód od Jerozolimy, stanowiła doskonały punkt do blokowania żydowskich konwojów z zaopatrzeniem dla tego miasta. Stąd po opuszczeniu jej przez arabską ludność cywilną na początku kwietnia 1948 r. zajęta została przez siły żydowskie. Był to zarazem wstęp do żydowskiej operacji „Nachszon”, będącej realizacją „Planu Dalet”. Al-Husajni zdawał sobie sprawę ze znaczenia tego miejsca i zdecydował się poprowadzić 5 kwietnia atak na wieś. W trakcie trwających działań Arabowie podjęli decyzję o wykorzystaniu ładunków wybuchowych, które zostały rozmieszczone w wiosce. Zostały one jednak dostrzeżone i rozbrojone przez siły Hagany. Al-Husajni zdecydował się przeprowadzić rozpoznanie osobiście i sprawdzić, dlaczego nie doszło do wybuchu. Prawdopodobnie wówczas został zastrzelony (8 kwietnia). Armia Świętej Wojny prowadziła jednak działania dalej, opanowała Kastel, ciało al-Kadira zostało odnalezione. Pogrzeb dowódcy Armii Świętej Wojny 9 kwietnia w Jerozolimie stał się manifetacją polityczną i nacjonalistyczną ${ }^{55}$.

Walka o niepodległość Palestyny, zahamowanie wprowadzenia w życie rezolucji ONZ nr 181, ochrona arabskiej ludności cywilnej stały się podstawowym celami stawianymi przed obydwoma dowódcami sił ochotniczych przez komitet militarny w Damaszku. Każdy z nich miał jednak inne doświadczenie wojskowe, zdecydowanie większe było ono po stronie al-Kawukdżiego. Jednak to al-Husajni walczył u siebie, o swoją ziemię, wywodził się wszakże z jednej z najznamienitszych rodzin w Mandacie Palestyny. Obaj musieli zmierzyć się z doskonale - jak na warunki mandatowe - wyszkolonymi siłami żydowskimi: Haganą i elitarnym Palmachem oraz organizacjami o charakterze terrorystycznym: Irgunem oraz Lechi. Postawili naprzeciwko nich siły ochotnicze, mało liczne, słabo wyszkolone. Obaj borykali się z podobnymi problemami: brakiem uzbrojenia, małą liczebnością formacji, brakiem czasu na prawidłowe przeszkolenie, niedoborami finansowymi. Zarówno Armia Świętej Wojny, jak i Arabska Armia Wyzwolenia operowały na większości obszaru Palestyny, co powodowało

53 „PM”, 3 II 1948, s. 7.

54 The British Record of Partition, „The Nation” 1948, vol. CLXVI, part 2, s. 13.

${ }_{55}$ Bitwa została szczegółowo opisana we wspomnieniach Bahjata Abu Garbiji przetłumaczonych przez Walida Khalidiego. Vide: The Fall of Qastel and the Death of Abd al-Kadir, „Journal of Palestine Studies" 1998, vol. XXVII, No. 3, s. 72-89. 
trudności w komunikowaniu się z poszczególnymi batalionami. Nie powstały też żadne plany operacyjne i taktyczne, które ułatwiłyby im prowadzenie skoordynowanej walki. Al-Kawukdżi - jak się wydaje - miał mniej swobody, zależny był bowiem od komitetu militarnego w Damaszku i właściwie został skazany przez niego na porażkę. Niejasne były: jego układy z królem Abdullahem; kontakty ze stroną żydowską; przyczyny bierności, jeśli idzie o pomoc al-Kadirowi al-Husajniemu. W dużej mierze była ona spowodowana ambicjami muftiego Haj Amina al-Husajniego. Brak jedności spowodował osłabienie w walce z siłami żydowskimi. Największy wpływ na ich możliwości jako dowódców miała wielka polityka, zarówno ta międzynarodowa, jak i ta regionalna. Jeśli idzie o tę pierwszą, zasadnicze znaczenie miało wsparcie dla Żydów w postaci dostaw uzbrojenia z Europy. W drugiej kwestii szczególnie rywalizacja między Saudami, Haszymidami a Syryjczykami negatywnie odbijała się na możliwościach sił arabskich. Obaj dowódcy byli zdeterminowani, aby te trudności pokonywać, co zmuszało ich do wizyt w Damaszku i tym samym na nieobecność w Palestynie. To postaci charyzmatyczne, cieszące się ogromną popularnością wśród swoich żołnierzy. Niejednokrotnie podejmowali ambitne działania mające zapewnić im zwycięstwo w walce z Żydami, jednak nie dysponowali siłami, które by im go umożliwiły. Al-Husajni zapłacił życiem za walkę o niepodległość Palestyny, ale został bohaterem narodowym. Al-Kawukdżi do końca życia musiał tłumaczyć się z poniesionej porażki i uzasadniać słuszność podejmowanych decyzji.

\section{Bibliografia}

\section{ŹróDEA ARCHIWALNE}

Israel State Archive

P 3056/38.

\section{ŹRÓDEA DRUKOWANE}

al-Qawuqji F., Memoirs, 1948, Part I, „Journal of Palestine Studies” 1972, vol. I, No. 4, s. 27-58. al-Qawuqji F., Memoirs, 1948, Part II, „Journal of Palestine Studies” 1972, vol. II, No. 1, s. 3-33. Bliski Wschód: dokumentacja konfliktu. Seria monograficzna, z. 3 (184), Warszawa 1983.

Documents of Palestine, ed. M.A. Hadi, vol. I, Jerusalem 2007.

Foreign Relation of United States, 1948, vol. V (The Near East, South Asia and Africa), part 2, Washington 1976.

Jamsheer H., Konflikt Bliskowschodni. Zarys i dokumentacja, Płock 2004.

Khalidi W., Selected Documents on the 1948 Palestine War, „Journal of Palestine Studies” 1998, vol. XXVII, No. 3, s. 60-105. 
Nasser G.A., Nasser's Memoirs of the First Palestine War, „Journal of Palestine Studies” 1973, vol. II, No. 2, s. 3-32.

United Nations Official Record of the Second Special Session of the General Assembly, Suplement No. 2, New York 1948.

\section{Prasa}

„PM” 1948.

„The Nation” 1948.

\section{Opracowania}

Ezov A., Arab army vs. a Jewish kibbutz: the battle of Mishmar Ha'emek, April 1948, „Israel Affairs" 2016, vol. XXII, No. 1, s. 96-125.

Hirszowicz Ł., III Rzesza i Arabski Wschód, Warszawa 1963.

Hopp G., Ruhmloses Zwischenspiel. Fawzi al-Qawuqji in Deutschland 1941-1947, [w:] Al-Rafidayn. Jarhbuch zu Geschichte und Kultur des modernen Iraq, hrsg. P. Heine, Wurzburg 1995, s. 19-46.

Hughes M., Britain's Pacification of Palestine. The British Army, the Colonial State, and the Arab Revolt, 1936-1939, Cambridge 2019.

Levenberg H., Military Preparations of the Arab Community in Palestine 1945-1948, London 1993.

McHugo J., Syria from the Great War to Civil War, London 2014.

Mohamed Hassanein Heikal, Reflections on a Nation in Crisis, 1948, „Journal of Palestine Studies" 1988, vol. XVIII, No. 1, s. 112-120.

Pappe I., The Rise and Fall of a Palestinian Dynasty, The Husaynis 1700-1948, Berkeley-Los Angeles 2010.

Parsons L., The Commander, Fawzi al-Qawuqji and the Fight for Arab Independence 1914-1948, New York 2017.

Patek A., Wieka Brytania wobec Izraela w okresie pierwszej wojny arabsko-izraelskiej maj 1948 - styczeń 1949, Kraków 2002.

Pipes D., Greater Syria. The History of an Ambition, New York 1990.

Pogońska-Pol M., Działalność Komisji Narodów Zjednoczonych do Spraw Palestyny 1947-1948, [w:] W kręgu zagadnień świata arabskiego, red. A. Abbas, A. Maśko, Poznań 2015, s. 335-348.

Pogońska-Pol M., Działalność Organizacji Narodów Zjednoczonych w czasie pierwszej wojny arabsko-izraelskiej 1948-1949, [w:] Bezpieczeństwo narodowe i międzynarodowe w regionie Bliskiego Wschodu i Pótnocnej Afryki (MENA) u progu XXI wieku, red. R. Bania, K. Zdulski, Łódź 2012, s. 297-309.

Radai I., Palestinians in Jerusalem and Jaffa, 1948. A tales of two cities, London-New York 2016.

Robin B., Schwanitz W.G., Hitlerowcy, islamiści i narodziny nowożytnego Bliskiego Wschodu, Kraków 2014.

Swedenburg T., Memories of Revolt. The 1936-1939 Rebellion and the Palestinian National Past, Fayetteville 2003.

Tal D., War in Palestine 1948. Strategy and Diplomacy, London-New York 2004.

Talhami G.H., Syria and the Palestinians. The Clash of Nationalisms, Gainesville 2001. 
Tauber E., The Arab Military Force in Palestine Prior to the Invasion of the Arab Armies 1945-1948, „Middle Eastern Studies” 2015, vol. LI, No. 6, s. 950-985.

Tauber E., Palestine 1948: the cryptography of the Arab volunteers, „Journal of the Intelligence History" 2013, vol. XII, No. 1, s. 36-48.

Tessler M.A., A History of the Israeli-Palestinian Conflict, Bloomongton-Indianapolis 1994.

The Military Situations in Palestine in the eve of Plan Dalet, „Journal of Palestine Studies” 1990, vol. XXVII, No. 3, s. 62-72.

Wróblewski B., Legion Arabski (1920-1957), Torun 2009.

Yitzhak R., The Question of Arab Solidarity in the 1948 War: Political Interest versus Military Considerations, „Mediterranean Quarterly” 2008, vol. XIX, No. 2, s. 19-46.

Zdanowski J., Historia Bliskiego Wschodu w XX wieku, Wrocław 2010.

\section{NetOGRAFiA}

Abd al-Qadir al-Husseini, https:/www.paljourneys.org/en/biography/9831/abd-al-qadir-al-husseini (dostęp:12 VI 2018).

Asher D., The Arab Armies Invasion of Israel, May 1948 Interests and Implementation, http://institutobrasilisrael.org/cms/assets/uploads/_BIBLIOTECA/_PDF/o-conflito-a\%CC\%81rabe-israelense/ e3a7b434ee05a3364268abcb818e9ff4.pdf (dostęp: 11 IX 2018).

\section{Magdalena Pogońska-Pol}

\section{Fawzi al-Qawuqji and Abd al-Qadir al-Husayni in the struggle for the independence of Palestine}

$\mathrm{T}$

he main of this article is presents actions taken by Fawzi al-Qawuqji and Abd al-Qadir al-Husayni during the so-called civil war in the British mandate of Palestine. The first headed the Arab Liberation Army, created by the League of Arab States. His forces were voluntary, few and weakly armed. The second set up the Holy War Army, which consisted of Palestinian volunteers, constituted forces subordinate to the Husajni family. Both commanders were to prevent the entry into force of the UN resolution on the division of Palestine into two states, and to protect the Arab civilian population. They conducted operations without cooperation, they failed to stop the activities of Jewish settlers and forces.

Keywords: Fawzi al-Qawuqji, Abd al-Qadir al-Husayni, civil war, Palestine Mandate, 1948. 